\title{
GROWTH AND DEVELOPMENT OF COMMON BEAN (PHASEOLUS VULGARIS L.) VAR. PINTO SALTILLO EXPOSED TO IRON, TITANIUM, AND ZINC OXIDE NANOPARTICLES IN AN AGRICULTURAL SOIL
}

\author{
MEdinA-PÉREZ, G. ${ }^{1}$ - FERNÁNDEZ-LUQUEÑO, F. ${ }^{2 *}$-TREJO-TÉLLEZ, L. I. ${ }^{3}$ - LÓPEZ-VALDEZ, F. ${ }^{4}$ - \\ PAMPILLÓN-GONZÁLEZ, L. ${ }^{5}$ \\ ${ }^{I}$ Transdisciplinary Doctoral Program in Scientific and Technological Development for the \\ Society, Cinvestav, Zacatenco, Mexico City, C. P. 07360, Mexico \\ ${ }^{2}$ Sustainability of Natural Resources and Energy Program, Cinvestav-Saltillo, Coahuila de \\ Zaragoza, C. P. 25900, Mexico \\ ${ }^{3}$ Colegio de Postgraduados, Campus Montecillo, Carretera Mexico-Texcoco km 36, C. P. \\ 56230, Mexico \\ ${ }^{4}$ Instituto Politécnico Nacional, CIBA-IPN, Tepetitla de Lardizábal, C. P. 90700, Tlaxcala, \\ Mexico \\ ${ }^{5}$ División Académica de Ciencias Biológicas, UJAT, Carretera Villahermosa-Cárdenas Km 0.5, \\ C.P. 86100, Tabasco, Mexico \\ *Corresponding author \\ e-mail: cinves.cp.cha.luqueno@gmail.com; phone: +52-844-438-9625 \\ (Received $29^{\text {th }}$ Nov 2017; accepted $7^{\text {th }}$ Mar 2018)
}

\begin{abstract}
Sustainable use of nanoparticles (NP) in the agriculture requires a deep understanding in order to determine their benefits potential as well as their toxicological impacts. Common bean plants were growing and irrigated with suspensions of magnetite, ferrihydrite, hematite, zinc oxide, or titanium dioxide $\mathrm{NP}$ at 0,3 , or $6 \mathrm{~g} \mathrm{~L}^{-1}$ in a 120 days' greenhouse experiment, in order to investigate the effect of these NP on growth and development of common bean. None of the five NP modified significantly the chlorophyll content of common bean plants, while at least one concentration of hematite, ferrihydrite or magnetite increased significantly the total $\mathrm{N}$ of roots or shoots, the number of pods, dry weight of pods, the number of seeds, and yield of common bean. Additionally, at least one concentration of zinc oxide or titanium dioxide decreased significantly the number of pods, the fresh weight of pods and the number of seeds. These finds are an important factor to take into account with regard to the applicability of NP for long-term use in crops, but the selection of the proper NP at their adequate concentration is important for realizing higher benefits for an agrosustainable target.

Keywords: agro-food industry, agronanotechnology, chlorophyll content, potential hazard or risk of nanoparticles, sustainable development, nanofertilizer, Phaseolus vulgaris $L$.
\end{abstract}

\section{Introduction}

While nanoparticles (NP) occur naturally in the environment and have been intentionally used for centuries, the production and use of engineered NP has seen a recent spike, which makes environmental release almost certain (Maurer-Jones et al., 2013). Keller et al. (2013) estimated that $63-91 \%$ of over $260,000-309,000$ metric tons of global engineered nanomaterials production in 2010 ended up in landfills, with the balance released into soils $(8-28 \%)$, water bodies $(0.4-7 \%)$, and atmosphere $(0.1-$ $1.5 \%)$. It is well known that hundreds of NP are being used worldwide in a wide range 
of products or devices, however, at our knowledge there are not standardized techniques nor laws governing the proper management of NP during their production, distribution, use, and confinement. This implies that NP may be released into the environment despite their potential harmful effects on human and environmental health.

Among some properties that comprise the bean are their high content of iron, vital for a proper brain development, help to correct biliary disorders, rheumatic diseases, lower cholesterol level and is effective against anemia, and their consumption can prevent some types of cancer. Per 100 common bean grams, $20 \mathrm{~g}$ are protein, $5.8 \mathrm{~g}$ are fat and $3 \mathrm{~g}$ are fiber (Lépiz et al., 2010).

In some prior research conducted on this topic, the results were varied, some of them showed favorable aspects due to the use of nanoparticles as the case of Ma et al. (2010), whose experimental data evinced that the $\mathrm{TiO}_{2}$ nanoparticles at concentrations of 2.5-40 $\mathrm{g} \mathrm{kg}^{-1}$ soil, improved the growth of the spinach. Other results exhibited no significant effects, as presented by Doshi et al. (2008), where aluminum nanoparticles did not show a significant effect on common bean studies performed in sand columns with concentrations up to $17 \mathrm{mg} \mathrm{L}^{-1}$ of aluminum. In addition, some studies present negative effects on the development and growth of established crops. Canas et al. (2008) indicated that monolayer carbon nanotubes caused significant affectations in the root elongation of crops such as tomato, cabbage, carrot and lettuce.

There have been published some studies that intend to demonstrate that some metallic NP are able to increase the growth and development of some crops, i.e., the NP are used as if they were fertilizers (Burke et al., 2015; Rico et al., 2011). However, the potential effect of NP on yield and yield components has not been studied when NP are considered as a collateral consequence of the NP polluted environment. It is still a challenge assessing most of the effect of NP in natural soils. It should be noted that NP have different pathways, effects, fates and behaviors that might vary within living organisms, soils and contaminants (Cornelis et al., 2014; Rodrigues et al., 2016). In this regard, the objective of this research was to investigate the effect of different nanoparticles such as iron, titanium and zinc oxide on growth and development of common bean plants cropped in an agricultural soil under greenhouse conditions, as a contribution to the new emerging field called econanotoxicology.

\section{Materials and methods}

\section{Experimental site}

This study was carried out in a greenhouse of the 'Programa de Sustentabilidad de los Recursos Naturales y Energía del Cinvestav-Saltillo' located in Saltillo, Coahuila, Mexico. This area is located in the southeastern state of Coahuila, centered at $25^{\circ} 31^{\prime} \mathrm{N}$, $101^{\circ} 37^{\prime} \mathrm{W}$, at an altitude of $1,600 \mathrm{~m}$ above sea level. According to FAO/UNESCO soil classification system, the soil is a Haplic Xerosol with $\mathrm{pH} 7.3$ and electrolytic conductivity $4.8 \mathrm{dS} \mathrm{m}$, a water holding capacity (WHC) of $865 \mathrm{~g} \mathrm{~kg}^{-1}$, an organic carbon content of $1.5 \mathrm{~g} \mathrm{C} \mathrm{kg}^{-1}$ soil, and a total $\mathrm{N}$ content of $0.7 \mathrm{~g} \mathrm{~N} \mathrm{~kg}^{-1}$ soil.

\section{Biological material}

Common bean seeds were donated by 'INIFAP-Celaya, Mexico'. All seeds were kept in the dark at $4{ }^{\circ} \mathrm{C}$ until use. Pinto Saltillo was developed to solve the problem of 
traditional varieties of 'pinto' type, which has a reduced postharvest life, due to the accelerated darkening of the seed coat.

\section{Nanomaterials}

Nanoparticles of magnetite, ferrihydrite and hematite were manufactured according to Pariona (2012), while nanoparticles of zinc oxide and titanium dioxide were purchased from 'Materiales nanoestructurados S.A de C.V. (San Luis Potosí, México)'. Its crystallographic system was cubic, hexagonal or tetragonal (Table 1). The X-ray diffraction was conducted to verify the pure phase samples (Fig. 1), and the magnetic properties of the samples were measured by MicroMagTM 2900 Alternating Gradient Magnetometer (Fig. 2).

Table 1. Physicochemical characteristics of nanoparticles used to irrigate common bean crop (Phaseolus vulgaris L.) in a 120 days greenhouse experiment.

\begin{tabular}{c|c|c|c|c|c}
\hline Oxide & $\begin{array}{c}\text { Molecular } \\
\text { formula }\end{array}$ & Color & $\begin{array}{c}\text { Particle } \\
\text { size }\end{array}$ & $\begin{array}{c}\text { Crystallographic } \\
\text { system }\end{array}$ & Magnetic properties \\
\hline Magnetite & $\mathrm{Fe}_{3} \mathrm{O}_{4}$ & Black & 6 a $20 \mathrm{~nm}$ & Cubic & Superparamagnetic \\
Ferrihydrite & $\mathrm{FeOOH} \mathrm{xH}_{2} \mathrm{O}$ & Dark brown & 2 a $3 \mathrm{~nm}$ & Hexagonal & Antiferromagnetic \\
Hematite & $\alpha-\mathrm{Fe}_{2} \mathrm{O}_{3}$ & Red ochre & 80 a $94 \mathrm{~nm}$ & Hexagonal & Weakly antiferromagnetic \\
Zinc oxide & $\mathrm{ZnO}_{\text {Tide }}$ & White & $<50 \mathrm{~nm}$ & Tetragonal & Weakly ferromagnetic \\
Titanium dioxide & $\mathrm{TiO}_{2}$ & White & $<50 \mathrm{~nm}$ & Hexagonal & Weakly ferromagnetic \\
\hline
\end{tabular}

\section{Cultivation of plants in the greenhouse}

The full experimental setup was repeated three times. The first one was carried out from January to May, 2016, the second one, from February to June, 2016, and the third one from March to July, 2016. Sixty sub-samples of 3,500 g soil, i.e., five kinds of nanoparticles (nano- $\mathrm{Fe}_{3} \mathrm{O}_{4}$, nano- $\mathrm{FeOOH} \cdot \mathrm{xH}_{2} \mathrm{O}$, nano- $\alpha-\mathrm{Fe}_{2} \mathrm{O}_{3}$, nano- $\mathrm{ZnO}$, and nano$\left.\mathrm{TiO}_{2}\right) \times$ three replicates $\times$ four concentrations, were added to square plastic pots whose length, width, and height were $17 \times 15 \times 17 \mathrm{~cm}$, respectively. Five treatments (nanoparticles) at four concentrations (zero, one, three, and six $\mathrm{g} \mathrm{L}^{-1}$ ) were applied to the soil during irrigation so that we sprayed each plastic pot with $500 \mathrm{~mL}$ of a zero, one, three, or six $g$ nano $\mathrm{L}^{-1}$ suspension, throughout the experiment. Three seeds of common bean were planted in one hundred and eighty plastic pots, i.e., five nanoparticles $\times$ three replicates $\times$ four concentrations on three experiments. The seeds were placed at two $\mathrm{cm}$ depth in each plastic pot. Five days after planting, the seedlings were thinned to one plant per plastic pot. The plastic pots were placed in the greenhouse for 120 days. A plastic container was placed under each plastic pot to collect drained liquid. However, irrigation was well controlled so that no leaching was observed. Thirty, 60 and 120 days after sowing, three plastic pots were selected at random from each treatment and each concentration. The entire soil column was removed from the plastic pot and the 0-7.5 $\mathrm{cm}$ and 7.5-15 $\mathrm{cm}$ depth, where the samples were taken with care not to damage the root structure. The roots were manually separated from the shoots of the plant. Then the soil was carefully disaggregated with the hands to avoid the rupture of the roots. Subsequently, the soil was sifted gently to extract the pieces of root that may have been left in it, in order to be sure that $100 \%$ of the roots were removed, washed and weighed. After that, the root was extended and measured along with the shoots length. The roots 
and shoots were dried at $70{ }^{\circ} \mathrm{C}$, were weighed and analyzed for $\mathrm{Ti}, \mathrm{Fe}, \mathrm{Zn}$, and total $\mathrm{N}$. The soils from 0-7.5 $\mathrm{cm}$ and 7.5-15 $\mathrm{cm}$ of depth were analyzed for $\mathrm{pH}, \mathrm{CE}, \mathrm{Ti}, \mathrm{Fe}$, and $\mathrm{Zn}$. The amount of chlorophyll was quantified every two days after sowing, beginning at day 15 (Fig. 3). The temperature and moisture content inside the greenhouse during the experiment were $24{ }^{\circ} \mathrm{C}$ and $35-45 \%$, respectively.
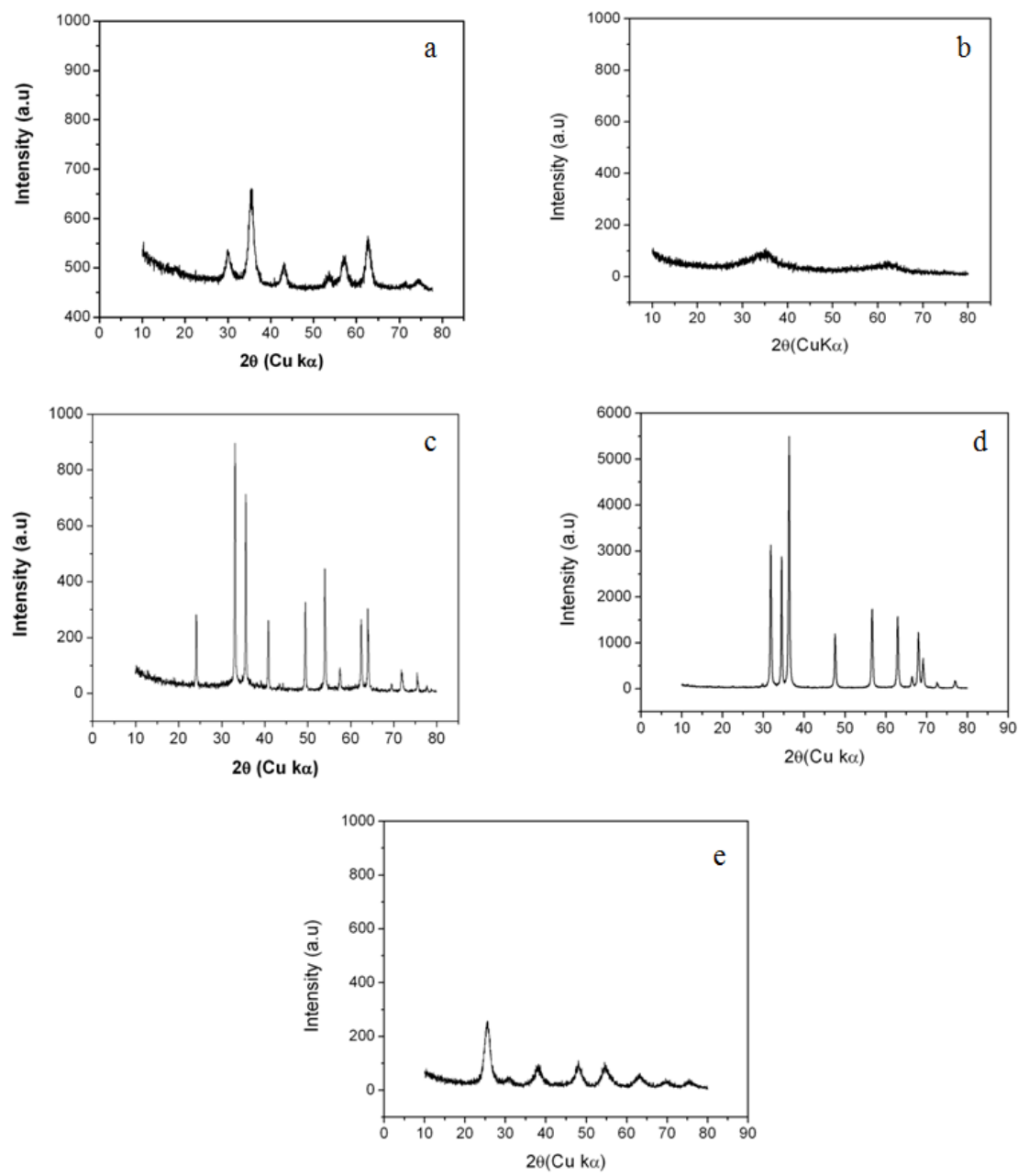

Figure 1. X-ray diffraction patterns of nanoparticles of a) Magnetite, b) Ferrihydrite, c) Hematite, d) $\mathrm{ZnO}$, and e) $\mathrm{TiO}_{2}$.

\section{Chemical analyses}

The $\mathrm{pH}$ was measured in 1:2.5 soil or wastewater sludge/ $\mathrm{H}_{2} \mathrm{O}$ suspension using a 716 DMS Titrino pH meter (Metrohm Ltd. CH.-901, Herisau, Switzerland) fitted with a glass electrode (Thomas, 1996). The EC was determined in a 1:5 soil/ $\mathrm{H}_{2} \mathrm{O}$ suspension as described by Rhoades et al. (1989). The organic C in soil was measured in a total organic carbon analyzer TOC-VCSN (SHIMADZU, USA). The inorganic $\mathrm{C}$ was determined by adding $5 \mathrm{~mL} 1 \mathrm{M}$ hydrogen chloride ( $\mathrm{HCl}$ ) solution to $1 \mathrm{~g}$ air-dried soil and trapping $\mathrm{CO}_{2}$ evolved in $20 \mathrm{~mL} 1 \mathrm{M} \mathrm{NaOH}$. Total $\mathrm{N}$ in soil, root and shoot was measured by the Kjeldahl method using concentrated $\mathrm{H}_{2} \mathrm{SO}_{4}, \mathrm{~K}_{2} \mathrm{SO}_{4}$ and $\mathrm{CuSO}_{4}$ to digest the sample (Bremner, 1996). Soil particle size distribution was defined by the hydrometer method as described by Gee and Bauder (1986). Water holding capacity 
was measured on $6.5 \mathrm{~kg}$ soil placed in a PVC tube (length $50 \mathrm{~cm}$ and $\varnothing 16 \mathrm{~cm}$ ), watersaturated, stoppered with a PVC ring and left to stand overnight to drain freely. The WHC is defined as (Gardner, 1986), WHC $=$ [(soil water-saturated - soil dried at $105^{\circ} \mathrm{C}$ ) / soil dried at $\left.105^{\circ} \mathrm{C}\right] * 1000$. The units of WHC are expressed in $\mathrm{g} \mathrm{kg}^{-1}$. The amount of chlorophyll was measured with a Minolta SPAD-502 Chorophyll meter (Markwell et al., 1995). The Fe, Ti and $\mathrm{Zn}$ were determined by inductively coupled plasma mass spectrometry (ICP-MS).
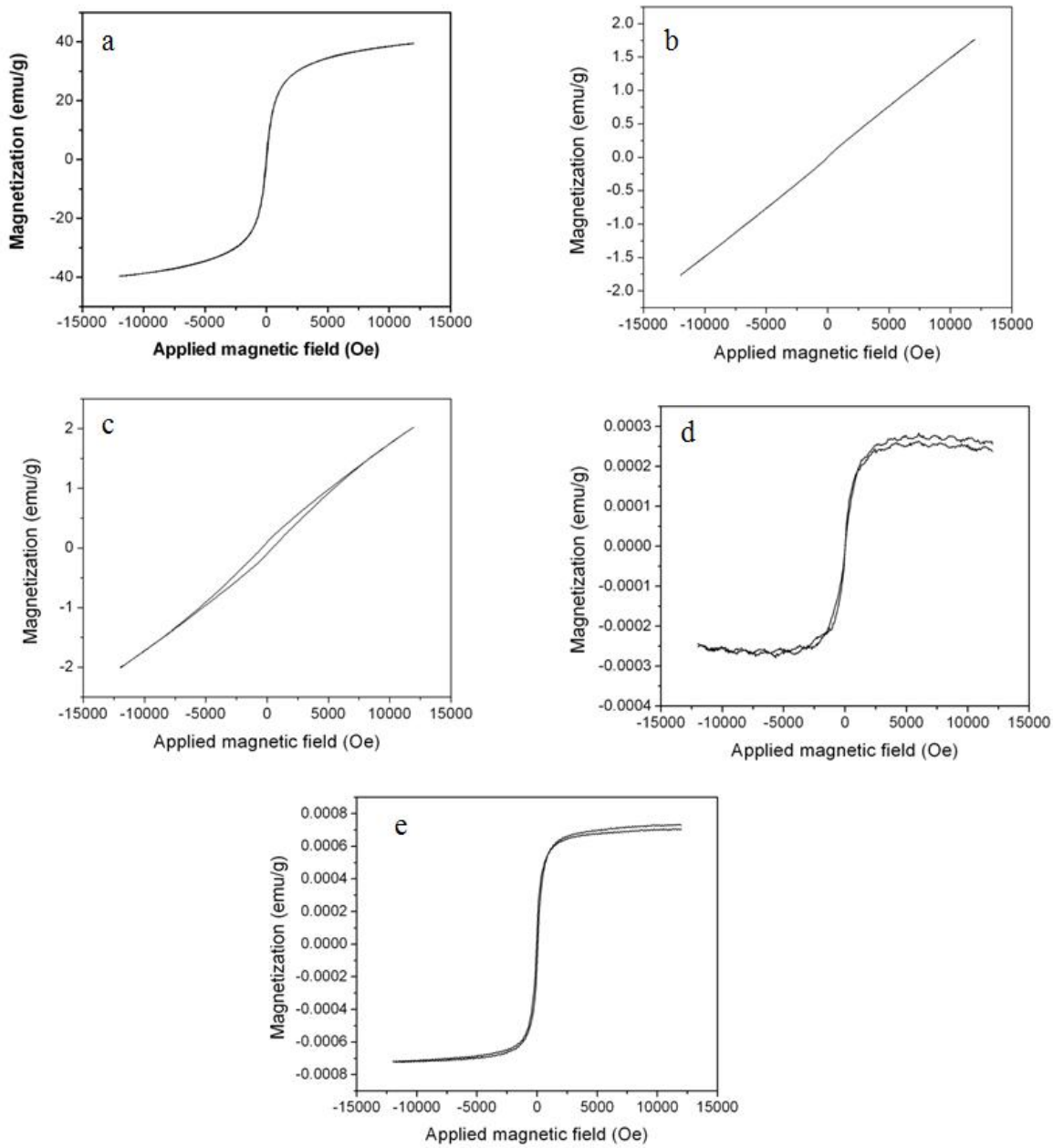

Figure 2. Magnetization curves of a) Magnetite, b) Ferrihydrite, c) Hematite, d) $\mathrm{ZnO}$ and e) $\mathrm{TiO}_{2}$.

\section{Statistical analyses}

The data were subjected to an analysis of variance (ANOVA) and means compared with the Tukey test using Statistical Analysis System (SAS) software version 8.0 for Windows (SAS Institute, 1989). Soil and plant characteristics were subjected to oneway analysis of variance using a general lineal models procedure (PROC GLM) to test for significant differences between treatments $(\mathrm{P}<0.05)$. Methodology for PCA analysis may be found in Fernández-Luqueño et al. (2016). All analyses were performed using the SAS statistical package (SAS Institute, 1989). All data presented 
were the mean of three replicates in soil from three different plots, while the whole experiment was repeated three times $(n=27)$, sampled after 30,60 , and 120 days.

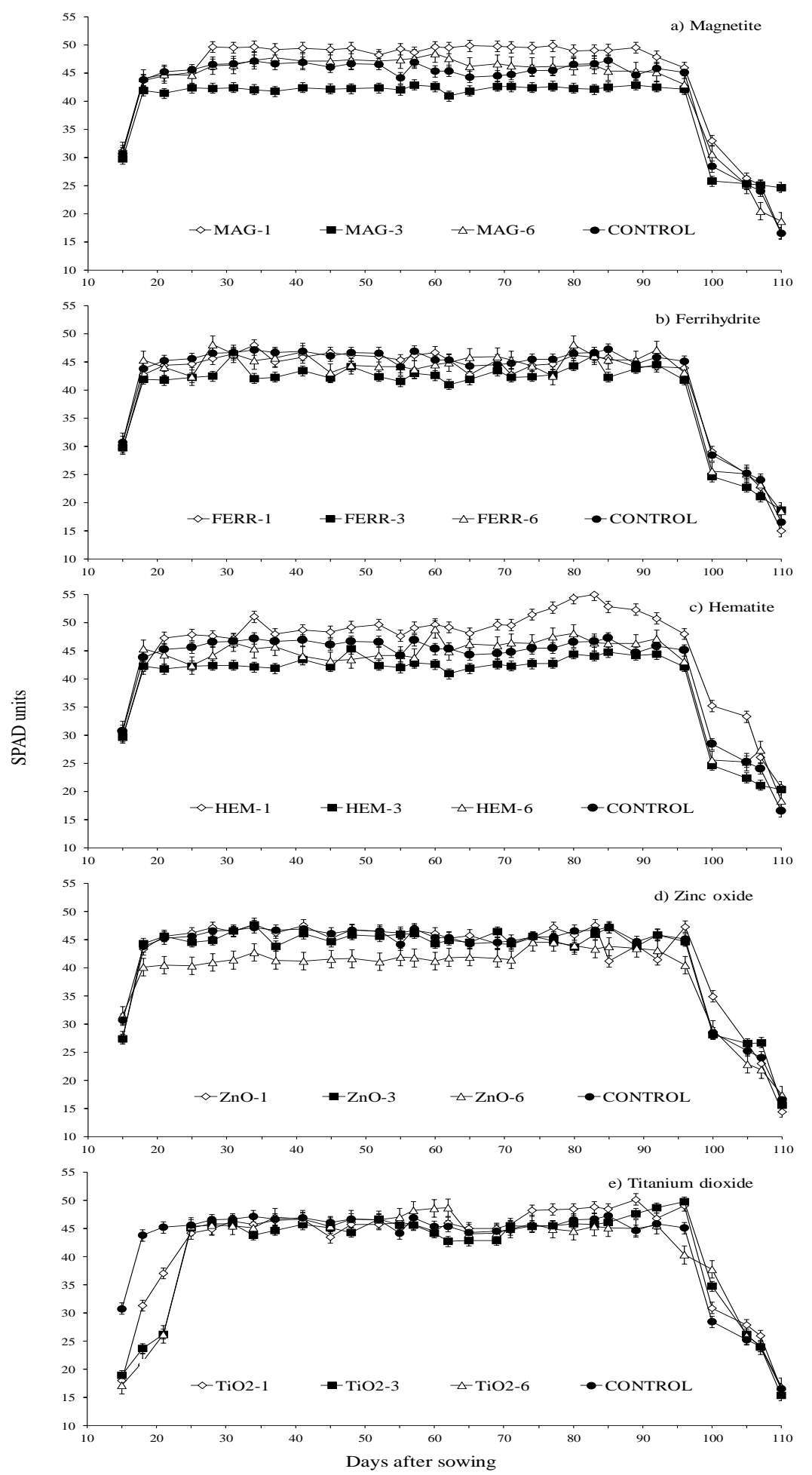

Figure 3. SPAD units of bean plants (Phaseolus vulgaris L.) cultivated in an agricultural soil irrigated with $500 \mathrm{~mL}$ of zero, one, three, or six $g$ nanoparticle $L^{-1}$ suspension. Nanoparticles of $\mathrm{Fe}_{3} \mathrm{O}_{4}, \mathrm{FeOOH} \cdot \mathrm{xH}_{2} \mathrm{O}, \alpha-\mathrm{Fe}_{2} \mathrm{O}_{3}, \mathrm{ZnO}$, and $\mathrm{TiO}_{2}$ were used. Data are the mean of three pots $\times$ three different soils $\times$ three experiments $\times$ three measurements by each plant, i.e., $n=81$. Each experiment lasted 120 days. 


\section{Results}

\section{SPAD units}

The concentration of the chlorophyll quantified on leaves of common bean plants cultivated in an agricultural soil irrigated with $500 \mathrm{~mL}$ of zero, one, three, or six $\mathrm{g}$ nanoparticle $\mathrm{L}^{-1}$ suspension, during 120 days after sowing is shown in Figure 3. SPAD Units data are related to the chlorophyll content, which maintained slightly unchanged over the time with values between 40 to 50 SPAD units in most of the experiment, excepting the HEMATITE treatment (HEM-1) which the SPAD units reached 55. The lowers chlorophyll values were presented in all the treatments during the onset of the measurements and at the end of the growing stage, i.e., at 15 and 95 days after sowing, respectively.

\section{Plant characteristics and crop yield}

Most of the plant and yield characteristics (root fresh weight, root dry weight, root length, shoot fresh weight, shoot dry weight, shoot length, and SPAD units) were not significantly different between nanoparticles treatments, compared with the CONTROL treatment $(\mathrm{P}<0.05)$ (Table 2). FERRIHYDRITE treatments at 3 and $6 \mathrm{~g} \mathrm{~L}^{-1}$ and HEMATITE at $1 \mathrm{~g} \mathrm{~L}^{-1}$ increased significantly the concentration of total $\mathrm{N}$ in roots, compared with the CONTROL treatment. All FERRIHYDRITE treatments and HEMATITE at 3 and $6 \mathrm{~g} \mathrm{~L}^{-1}$ increased significantly the concentration of total $\mathrm{N}$ in shoots, compared with the CONTROL treatment (Table 2).

The MAGNETITE and FERRIHYDRITE treatments at $6 \mathrm{~g} \mathrm{~L}^{-1}$ increased significantly the number of pods, compared with the CONTROL treatment. However, the ZINC OXIDE and TITANIUM OXIDE treatments at $6 \mathrm{~g} \mathrm{~L}^{-1}$ decreased significantly the number of pods, compared with the CONTROL treatment (Table 2). The fresh weight of pods decreased significantly when plants were amended with MAGNENTITA or HEMATITE at 3 or $6 \mathrm{~g} \mathrm{~L}^{-1}$, and when they were amended with FERRIHYDRITE or ZINC OXIDE at $6 \mathrm{~g} \mathrm{~L}^{-1}$, compared with the CONTROL treatment (Table 2). The dry weight of pods decreased significantly when plants were amended with FERRYDRITE at $3 \mathrm{~g} \mathrm{~L}^{-1}$, but MAGNETITE at 3 or $6 \mathrm{~g} \mathrm{~L}^{-1}$ increased significantly the dry weight of pods, compared with the CONTROL treatment (Table 2). MAGNETITE and FERRIHYDRITE increased significantly the number of seeds when plants were amended with $6 \mathrm{~g} \mathrm{~L}^{-1}$, while HEMATITE increased it significantly when plants were amended with 3 or $6 \mathrm{~g} \mathrm{~L}^{-1}$. However, plants amended with ZINC OXIDE or TITANIUM DIOXIDE decreased significantly the number of seeds, compared to the

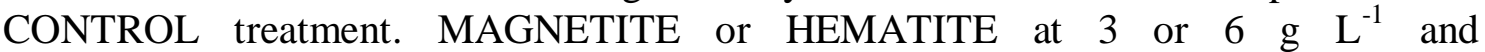
FERRIHYDRITE at $6 \mathrm{~g} \mathrm{~L}^{-1}$ increased significantly the yield, while ZINC OXIDE or TITANIUM DIOXIDE decreased it significantly, compared with the CONTROL treatment (Table 2). Nanoparticles did not affect significantly the SPAD units.

The seed number was strongly significantly correlated with fresh or dry weight of roots, length of root or shoot, total nitrogen of shoot, and with number, fresh or dry weight of pods (Table 3). Seed yield was strongly significantly correlated with fresh weight of root, total nitrogen of root, dry weight of shoot, total nitrogen of shoot, with number, fresh or dry weight of pods, and with seed number. In addition, SPAD units was strongly significantly correlated with total nitrogen of shoot and with yield (Table 3). 
Table 2. Characteristics of common bean (Phaseolus vulgaris L.) cultivated in an agricultural soil irrigated with $500 \mathrm{~mL}$ at zero, one, three, or six $g$ nanoparticle $L^{-1}$ suspension. The whole experiment was repeated three times (the first time, from January to May, 2016; the second one, from February to June, 2016; and the third one, from March to July, 2016). Each whole experiment lasted 120 days. Root and shoot data are the mean of values measured after 30, 60 and $120 \mathrm{~d}$, i.e., $n=81$. The pods and seeds data are the mean of values measured after $120 \mathrm{~d}$, i.e., $n=27$. SPAD unit's data are the mean of three measures twice a week during 14 weeks, i.e., $n=1,988(3$ soils $\times 3$ replicates $\times 3$ measures per plant $\times 3$ sampling dates $\times 2$ measures per week $\times 14$ weeks).

\begin{tabular}{|c|c|c|c|c|c|c|c|c|c|c|c|c|c|c|}
\hline \multirow[b]{2}{*}{$\begin{array}{l}\text { Treatments / } \\
\text { g NP L }^{-1}\end{array}$} & \multicolumn{4}{|c|}{$\operatorname{Root}^{\varnothing}$} & \multicolumn{4}{|c|}{ Shoot } & \multicolumn{3}{|c|}{ Pods } & \multicolumn{2}{|c|}{ Seeds } & \multirow{2}{*}{$\begin{array}{l}\text { SPAD } \\
\text { Units }\end{array}$} \\
\hline & $\begin{array}{c}\text { Fresh } \\
\text { weight }\end{array}$ & $\begin{array}{c}\text { Dry } \\
\text { weight }\end{array}$ & Length & $\begin{array}{c}\text { Total } \\
\text { Nitrogen }\end{array}$ & $\begin{array}{c}\text { Fresh } \\
\text { weight }\end{array}$ & $\begin{array}{c}\text { Dry } \\
\text { weight }\end{array}$ & Length & $\begin{array}{c}\text { Total } \\
\text { Nitrogen }\end{array}$ & Number & $\begin{array}{c}\text { Fresh } \\
\text { weight }\end{array}$ & $\begin{array}{c}\text { Dry } \\
\text { weight }\end{array}$ & Number & Yield & \\
\hline \multicolumn{15}{|l|}{ Control } \\
\hline \multicolumn{15}{|c|}{ Magnetite $\left(\mathrm{Fe}_{3} \mathrm{O}_{4}\right)$} \\
\hline 1 & $10.0 \mathrm{a}$ & $1.0 \mathrm{a}$ & $24.9 \mathrm{ab}$ & $26.4 \mathrm{bc}$ & $15.6 \mathrm{a}$ & $1.7 \mathrm{a}$ & $22.0 \mathrm{ab}$ & 30.3 cde & $15.7 \mathrm{bcd}$ & 20.9 cde & $5.9 \mathrm{c}$ & 48.7 cde & 3.9 defg & $38.4 \mathrm{a}$ \\
\hline 3 & $11.3 \mathrm{a}$ & $0.8 \mathrm{a}$ & $24.0 \mathrm{ab}$ & $28.9 \mathrm{abc}$ & $14.5 \mathrm{a}$ & $1.5 \mathrm{a}$ & $22.7 \mathrm{ab}$ & 29.8 cde & $16.3 \mathrm{bc}$ & $22.5 \mathrm{bc}$ & $6.6 \mathrm{ab}$ & 49.0 cde & $4.8 \mathrm{ab}$ & $35.8 \mathrm{ab}$ \\
\hline 6 & $13.5 \mathrm{a}$ & $1.2 \mathrm{a}$ & $19.0 \mathrm{ab}$ & $30.4 \mathrm{abc}$ & $17.3 \mathrm{a}$ & $1.9 \mathrm{a}$ & $25.9 \mathrm{~b}$ & $32.1 \mathrm{bcde}$ & $17.3 \mathrm{ab}$ & $26.0 \mathrm{a}$ & $7.1 \mathrm{a}$ & $64.3 \mathrm{a}$ & $4.7 \mathrm{bc}$ & $36.4 \mathrm{ab}$ \\
\hline 1 & $11.8 \mathrm{a}$ & $1.0 \mathrm{a}$ & $28.9 \mathrm{ab}$ & $30.5 \mathrm{abc}$ & $17.8 \mathrm{a}$ & $2.6 \mathrm{a}$ & $21.4 \mathrm{ab}$ & $33.8 \mathrm{abcd}$ & $14.7 \mathrm{~cd}$ & 20.7 cde & $5.5 \mathrm{~cd}$ & $55.0 \mathrm{bc}$ & $3.6 \mathrm{~g}$ & $36.0 \mathrm{ab}$ \\
\hline 3 & $11.6 \mathrm{a}$ & $1.1 \mathrm{a}$ & $27.8 \mathrm{ab}$ & $32.1 \mathrm{a}$ & $16.7 \mathrm{a}$ & $2.9 \mathrm{a}$ & $21.9 \mathrm{ab}$ & $34.9 \mathrm{abc}$ & $15.3 \mathrm{bcd}$ & $20.3 \mathrm{~cd}$ & $4.5 \mathrm{e}$ & $51.0 \mathrm{~cd}$ & $3.8 \mathrm{efg}$ & $36.0 \mathrm{ab}$ \\
\hline 6 & $12.3 \mathrm{a}$ & $1.3 \mathrm{a}$ & $27.1 \mathrm{ab}$ & $32.0 \mathrm{a}$ & $15.7 \mathrm{a}$ & $2.7 \mathrm{a}$ & $19.2 \mathrm{ab}$ & $35.0 \mathrm{abc}$ & $19.3 \mathrm{a}$ & $26.9 \mathrm{a}$ & $5.6 \mathrm{~cd}$ & $67.0 \mathrm{a}$ & $4.2 \mathrm{~cd}$ & $36.6 \mathrm{ab}$ \\
\hline \multicolumn{15}{|c|}{ Hematite $\left(\alpha-\mathrm{Fe}_{2} \mathrm{O}_{3}\right)$} \\
\hline 1 & $14.7 \mathrm{a}$ & $1.3 \mathrm{a}$ & $25.1 \mathrm{a}$ & $31.0 \mathrm{ab}$ & $18.3 \mathrm{a}$ & $3.0 \mathrm{a}$ & $20.2 \mathrm{ab}$ & $32.3 \mathrm{bcde}$ & $15.7 \mathrm{bcd}$ & $22.0 \mathrm{bcd}$ & $5.5 \mathrm{~cd}$ & $53.7 \mathrm{bcd}$ & $4.0 \mathrm{def}$ & $37.6 \mathrm{ab}$ \\
\hline 3 & $14.3 \mathrm{a}$ & $1.3 \mathrm{a}$ & $28.2 \mathrm{ab}$ & $30.0 \mathrm{abc}$ & $19.5 \mathrm{a}$ & $3.2 \mathrm{a}$ & $17.0 \mathrm{ab}$ & $37.2 \mathrm{ab}$ & $15.0 \mathrm{~cd}$ & $23.6 \mathrm{~b}$ & $5.9 \mathrm{c}$ & $60.0 \mathrm{ab}$ & $5.2 \mathrm{a}$ & $35.7 \mathrm{ab}$ \\
\hline 6 & $14.8 \mathrm{a}$ & $1.4 \mathrm{a}$ & $31.0 \mathrm{ab}$ & $30.0 \mathrm{abc}$ & $18.1 \mathrm{a}$ & $2.9 \mathrm{a}$ & $19.4 \mathrm{ab}$ & $38.5 \mathrm{a}$ & $16.0 \mathrm{bcd}$ & $25.9 \mathrm{a}$ & $5.9 \mathrm{bc}$ & $60.7 \mathrm{ab}$ & $5.1 \mathrm{a}$ & $36.6 \mathrm{ab}$ \\
\hline \multicolumn{15}{|c|}{ Zinc Oxide ( $\mathrm{ZnO})$} \\
\hline 3 & $11.9 \mathrm{a}$ & $1.0 \mathrm{a}$ & $19.6 \mathrm{ab}$ & $29.1 \mathrm{abc}$ & $15.5 \mathrm{a}$ & $2.2 \mathrm{a}$ & $15.7 \mathrm{a}$ & 30.2 cde & $15.3 \mathrm{bcd}$ & 21.1 cde & $5.5 \mathrm{~cd}$ & 40.7 ef & 3.9 defg & $34.9 \mathrm{ab}$ \\
\hline 6 & $13.1 \mathrm{a}$ & $0.8 \mathrm{a}$ & $21.1 \mathrm{ab}$ & $28.6 \mathrm{abc}$ & $16.8 \mathrm{a}$ & $2.6 \mathrm{a}$ & $18.2 \mathrm{ab}$ & 30.4 cde & $12.3 \mathrm{e}$ & $23.8 \mathrm{~b}$ & $5.2 \mathrm{cde}$ & $37.7 \mathrm{fg}$ & $4.1 \mathrm{de}$ & $36.7 \mathrm{ab}$ \\
\hline \multicolumn{15}{|c|}{ Titanium dioxide $\left(\mathrm{TiO}_{2}\right)$} \\
\hline 1 & $11.1 \mathrm{a}$ & $0.9 \mathrm{a}$ & $17.6 \mathrm{ab}$ & $27.7 \mathrm{abc}$ & $13.8 \mathrm{a}$ & $2.1 \mathrm{a}$ & $17.5 \mathrm{ab}$ & $28.3 \mathrm{e}$ & $14.0 \mathrm{de}$ & $19.2 \mathrm{e}$ & $5.0 \mathrm{de}$ & $31.3 \mathrm{gh}$ & 4.0 defg & $34.7 \mathrm{~b}$ \\
\hline 3 & $11.9 \mathrm{a}$ & $1.0 \mathrm{a}$ & $17.1 \mathrm{~b}$ & $30.0 \mathrm{abc}$ & $13.3 \mathrm{a}$ & $2.4 \mathrm{a}$ & $15.7 \mathrm{a}$ & $28.8 \mathrm{de}$ & $15.7 \mathrm{bcd}$ & $21.1 \mathrm{de}$ & $5.3 \mathrm{~cd}$ & $23.7 \mathrm{~h}$ & 3.9 defg & $35.7 \mathrm{ab}$ \\
\hline 6 & $11.5 \mathrm{a}$ & $1.0 \mathrm{a}$ & $22.0 \mathrm{ab}$ & $28.5 \mathrm{abc}$ & $18.2 \mathrm{a}$ & $2.0 \mathrm{a}$ & $16.3 \mathrm{a}$ & $29.5 \mathrm{de}$ & $12.0 \mathrm{e}$ & $21.9 \mathrm{bcd}$ & $5.0 \mathrm{de}$ & $26.3 \mathrm{~h}$ & $4.1 \mathrm{de}$ & $34.2 \mathrm{~b}$ \\
\hline $\mathrm{MSD}^{\pi}$ & 9.05 & 0.64 & 13.5 & 5.0 & 9.4 & 1.7 & 9.2 & 5.4 & 2.0 & 1.9 & 0.7 & 8.5 & 0.4 & 3.5 \\
\hline
\end{tabular}

${ }^{\emptyset}$ Fresh or dry weights are expressed in $\mathrm{g}$; Length is in $\mathrm{cm}$; Total nitrogen is in $\mathrm{g} \mathrm{N} \mathrm{kg}^{-1}$ dry plant; Yield is in $\mathrm{g}$ per plant.

$\Sigma$ Values with the same letter within the columns are not significantly different $(P<0.05)$.

${ }^{\pi}$ Minimum significant difference $(P<0.05)$. 
Table 3. Correlations between characteristics of common bean crop (Phaseolus vulgaris L.) cultivated in an agricultural soil irrigated with $500 \mathrm{~mL}$ at zero, one, three, or six $g N L^{-1}$ suspension. Data were pooled among five treatments, three soils and the three replicates of the whole experiment. Each experiment lasted 120 days.

\begin{tabular}{|c|c|c|c|c|c|c|c|c|c|c|c|c|c|}
\hline \multirow{2}{*}{$\begin{array}{c}\text { Plant } \\
\text { characteristics }\end{array}$} & \multicolumn{4}{|c|}{$\operatorname{Root}^{\boldsymbol{D}}$} & \multicolumn{4}{|c|}{ Shoot } & \multicolumn{3}{|c|}{ Pods } & \multicolumn{2}{|c|}{ Seeds } \\
\hline & $\begin{array}{c}\text { Fresh } \\
\text { weight }\end{array}$ & $\begin{array}{c}\text { Dry } \\
\text { weight }\end{array}$ & Length & $\begin{array}{c}\text { Total } \\
\text { Nitrogen }\end{array}$ & $\begin{array}{l}\text { Fresh } \\
\text { weight }\end{array}$ & $\begin{array}{c}\text { Dry } \\
\text { weight }\end{array}$ & Length & \begin{tabular}{|c|} 
Total \\
Nitrogen
\end{tabular} & Number & $\begin{array}{l}\text { Fresh } \\
\text { weight }\end{array}$ & $\begin{array}{c}\text { Dry } \\
\text { weight }\end{array}$ & Number & Yield \\
\hline Root dry weight & $0.867 * * *$ & & & & & & & & & & & & \\
\hline Root length & $0.891 * * *$ & $0.834 * * *$ & & & & & & & & & & & \\
\hline Root total N & $-0.238 * * *$ & 0.005 & $-0.289 * * *$ & & & & & & & & & & \\
\hline Shoot fresh weight & $0.839 * * *$ & $0.870 * * *$ & $0.762 * * *$ & 0.142 & & & & & & & & & \\
\hline Shoot dry weight & $0.894 * * *$ & $0.876^{* * * *}$ & $0.852 * * *$ & -0.062 & $0.883 * * *$ & & & & & & & & \\
\hline Shoot length & $0.848 * * *$ & $0.815^{* * *}$ & $0.809 * * *$ & -0.075 & $0.837 * * *$ & $0.780 * * *$ & & & & & & & \\
\hline Shoot Total N & -0.037 & $0.245 * * *$ & -0.041 & $0.839 * * *$ & $0.313 * * *$ & 0.150 & 0.121 & & & & & & \\
\hline Pods number & 0.279 & $0.428 * * *$ & 0.210 & 0.155 & -0.064 & -0.108 & $0.297 * * *$ & 0.166 & & & & & \\
\hline Pods fresh weight & $0.344 * * *$ & $0.462 * * *$ & 0.155 & $0.332 * * *$ & -0.278 & -0.121 & 0.078 & $0.501 * * *$ & $0.292 * * *$ & & & & \\
\hline Pods dry weight & 0.062 & $0.130 * * *$ & 0.023 & 0.005 & -0.218 & $-0.429 * * *$ & $0.379 * * *$ & 0.112 & 0.272 & $0.341 * * *$ & & & \\
\hline Seed number & $0.415^{* * *}$ & $0.616^{* * *}$ & $0.647 * * *$ & 0.058 & 0.115 & 0.195 & $0.492 * * *$ & $0.421 * * *$ & $0.480 * * *$ & $0.400 * * *$ & $0.343 * * *$ & & \\
\hline Seed yield & $0.200 * * *$ & 0.241 & 0.060 & $0.396 * * *$ & -0.183 & $-0.301 * * *$ & -0.013 & $0.622 * * *$ & $0.276^{* *}$ & $0.475 * * *$ & $0.295 * * *$ & $0.270 * * *$ & \\
\hline SPAD Units & -0.039 & 0.001 & -0.008 & 0.099 & -0.014 & -0.017 & 0.023 & $0.186^{* * * *}$ & 0.182 & $0.122 *$ & 0.121 & 0.149 & $0.341 * * *$ \\
\hline
\end{tabular}




\section{Principal component analysis}

Loading for parameters obtained after VARIMAX rotation are given in Table 4. The plants characteristics had three significant PCs. The first principal component (PC1) explained $31 \%$ of variation and was related to root fresh weight, root dry weight, root length, shoot total nitrogen, number of pods, pod fresh weight, seed yield, number of seeds, and SPAD units. The second principal component (PC2) explained 20\% of variation and was related to shoot fresh weight and shoot dry weight, while the third principal component (PC3) explained 14\% of variation and was related to root total nitrogen but negatively related to shoot length and pod dry weight. The three principal components explained $65 \%$ of variation (Table 4).

On the scatter plot with PC1 and PC2, the kinds of NP or their concentrations are clearly separated from each other (Fig. 4a). HEMATITE and FERRIHYDRITE can be found in the upper right quadrant, while MAGNETITE, ZINC OXIDE or TITANIUM DIOXIDE lie in the two left quadrants. The CONTROL treatment lies in the lower left quadrant (Fig. 4a). On the scatter plot with PC1 and PC3, the treatments are visually distinct (Fig. 4b). The HEMATITE, FERRIHYDRITE, and CONTROL treatments lie in the two-right quadrant, while MAGNETITE, ZINC OXIDE or TITANIUM DIOXIDE lie in the two left quadrants (Fig. $4 b$ ).

Table 4. Rotated loading on the PC of bean plants characteristics (Phaseolus vulgaris L.) cultivated in an agricultural soil irrigated with $500 \mathrm{~mL}$ at zero, one, three, or six $\mathrm{gNP} \mathrm{L}^{-1}$ suspension. $\mathrm{NP}$ of $\mathrm{Fe}_{3} \mathrm{O}_{4}, \mathrm{FeOOH} \bullet \mathrm{xH}_{2} \mathrm{O}, \alpha-\mathrm{Fe}_{2} \mathrm{O}_{3}, \mathrm{ZnO}$, and $\mathrm{TiO}_{2}$ were used. Data were pooled among the five treatments and three experiment repetitions. The whole experiment was repeated three times (from January to May 2015; the second one from February to June 2015; and the third one from March to July 2015). Each whole experiment lasted 120 days.

\begin{tabular}{c|c|c|c}
\hline \multirow{2}{*}{ Statistical and measurements } & \multicolumn{3}{|c}{ Principal components ${ }^{\text {a }}$} \\
\cline { 2 - 4 } & PC1 & PC2 & PC3 \\
\hline Eigenvalues & 4.27 & 2.83 & 1.94 \\
Proportions & 0.31 & 0.20 & 0.14 \\
\hline \multicolumn{4}{|c}{ Rotated loading on three retained components } \\
\hline Root fresh weight & $65^{*, \mathrm{~b}}$ & 14 & 30 \\
Root dry weight & $80^{*}$ & 32 & 5 \\
Root length & $67^{*}$ & 61 & -9 \\
Shoot fresh weight & 20 & $74^{*}$ & 10 \\
Shoot dry weight & 24 & $79^{*}$ & 42 \\
Shoot length & 35 & 12 & $-80^{*}$ \\
Root total nitrogen & 33 & -50 & $59^{*}$ \\
Shoot total nitrogen & $70^{*}$ & -31 & 44 \\
Number of pods & $57^{*}$ & -10 & -26 \\
Pod fresh weight & $64^{*}$ & -40 & 6 \\
Pod dry weight & 36 & -37 & $-54^{*}$ \\
Seed yield & $52^{*}$ & -60 & 12 \\
Number of seeds & $80^{*}$ & 17 & -29 \\
SPAD units & $43^{*}$ & -31 & -9 \\
\hline
\end{tabular}

${ }^{\mathrm{a}}$ Only principal components with Eigenvalues $>1$ and that explain $>10 \%$ the total variance were retained

${ }^{\mathrm{b}}$ Parameters with significant loading $(>0.4)$ on the within column principal component. 


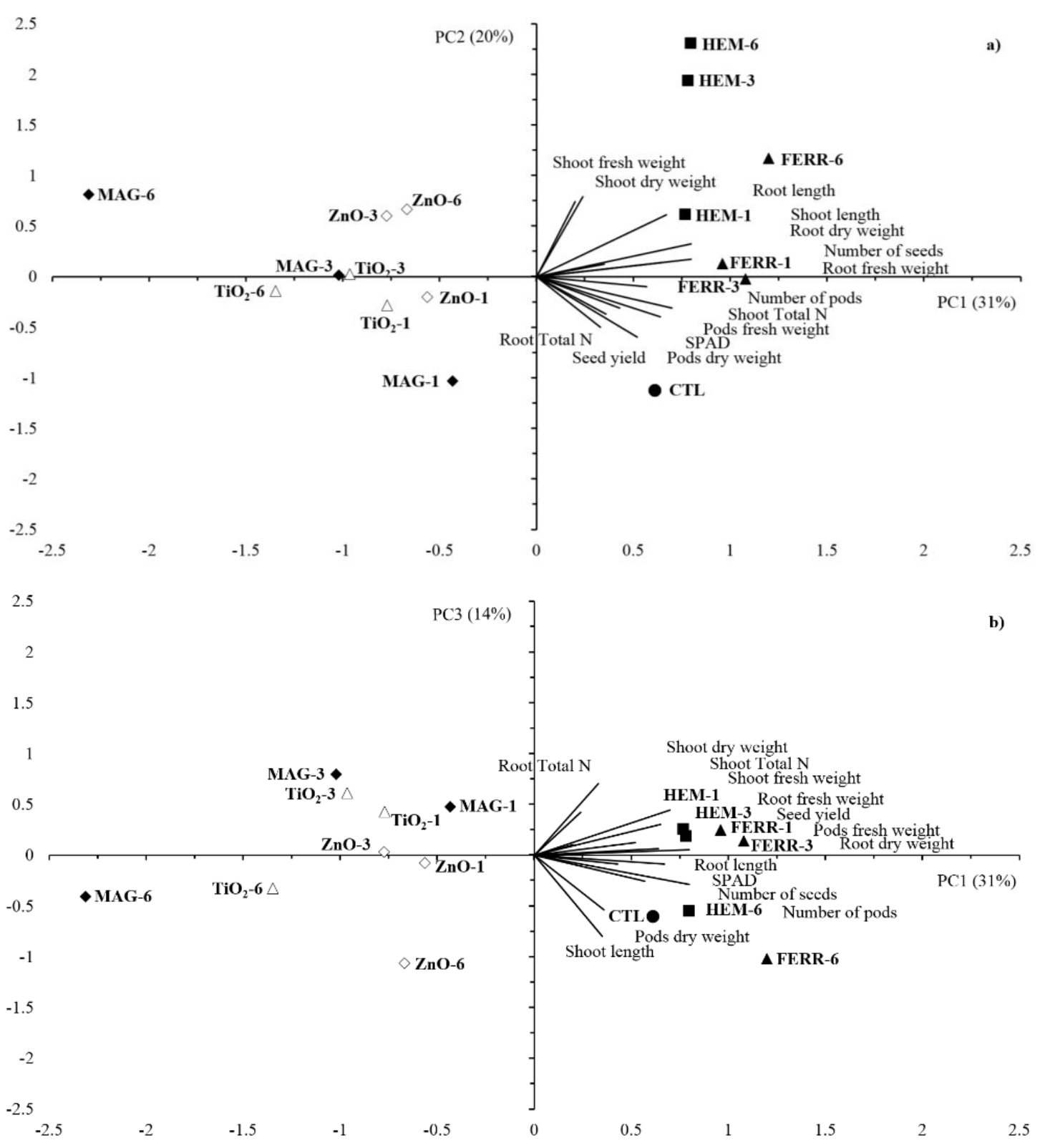

Figure 4. Principal component analysis performed on characteristics of bean plants (Phaseolus vulgaris L.) cultivated in an agricultural soil irrigated with $500 \mathrm{~mL}$ of zero, one, three, or six $\mathrm{g}$ nanoparticle $\mathrm{L}^{-1}$ suspension. Nanoparticles of $\mathrm{Fe}_{3} \mathrm{O}_{4}, \mathrm{FeOOH} \cdot \mathrm{xH}_{2} \mathrm{O}, \alpha-\mathrm{Fe}_{2} \mathrm{O}_{3}, \mathrm{ZnO}$, and $\mathrm{TiO}_{2}$ were used. Data are the mean of three square plastic pots with $3.5 \mathrm{~kg}$ dry soil each one, for three different soils and three experiments, i.e., $n=27$. Each whole experiment lasted 120 days. The first two factors explain 51\% of the variation. MAG-1 (500 mL of $1 \mathrm{~g} \mathrm{NP}-\mathrm{Fe}_{3} \mathrm{O}_{4}$ suspension), MAG-3 (500 mL of $3 \mathrm{~g} \mathrm{NP}-\mathrm{Fe}_{3} \mathrm{O}_{4}$ suspension), MAG-6 (500 $\mathrm{mL}$ of $6 \mathrm{~g} \mathrm{NP}-\mathrm{Fe}_{3} \mathrm{O}_{4}$ suspension); FERR-1 (500 mL of $1 \mathrm{~g} \mathrm{NP}-\mathrm{FeOOH} \bullet \mathrm{xH}_{2} \mathrm{O}$ suspension), FERR-3 (500 mL of $3 \mathrm{~g}$ $\mathrm{NP}-\mathrm{FeOOH} \bullet \mathrm{xH}_{2} \mathrm{O}$ suspension), FERR-6 (50O $\mathrm{mL}$ of $6 \mathrm{~g} \mathrm{NP}$-FeOOH$\bullet \mathrm{xH}_{2} \mathrm{O}$ suspension); HEM-1 (500 mL of $1 \mathrm{~g} \mathrm{NP}-\alpha-\mathrm{Fe}_{2} \mathrm{O}_{3}$ suspension), HEM-3 (500 mL of $3 \mathrm{~g} \mathrm{NP}-\alpha-\mathrm{Fe}_{2} \mathrm{O}_{3}$ suspension), HEM-6 (500 mL of $6 \mathrm{~g} \mathrm{NP}-\alpha-\mathrm{Fe}_{2} \mathrm{O}_{3}$ suspension); $\mathrm{ZnO}-1$ (500 mL of $1 \mathrm{~g} \mathrm{NP-ZnO} \mathrm{suspension),}$ $\mathrm{ZnO}-3$ (500 mL of $3 \mathrm{~g} \mathrm{NP}-\mathrm{ZnO}$ suspension), $\mathrm{ZnO}-6$ (500 mL of $6 \mathrm{~g} \mathrm{NP}-\mathrm{ZnO}$ suspension); $\mathrm{TiO}_{2}-1$ (500 $\mathrm{mL}$ of $1 \mathrm{~g} \mathrm{NP}-\mathrm{TiO}_{2}$ suspension), $\mathrm{TiO}_{2}-3$ (500 $\mathrm{mL}$ of $3 \mathrm{~g} \mathrm{NP}-\mathrm{TiO}_{2}$ suspension), and $\mathrm{TiO}_{2}-6$ (500 $\mathrm{mL}$ of $6 \mathrm{~g} \mathrm{NP}-\mathrm{TiO}_{2}$ suspension). 


\section{Discussion}

All treatments showed a lower chlorophyll content during the onset of the measurement at 15 days after sowing. This behavior suggests that the common bean plants were not in the fullness of the photosynthetic process. SPADS curves commonly show a decreasing trend due to the measurement was done leaf by leaf at the beginning of vegetative growth (Ribeiro de Cunha et al., 2015). About the SPAD units, Gómez et al. (2011) reported values near to 40 - 45 SPAD units. Anderson and Ryser (2015). However, measured leaves chlorophyll concentration in common bean reported range between 30 and 40 SPAD units. In this study, none of the treatments increased the chlorophyll content of bean plants, nevertheless the SPAD units' values are consistent with the values reported by other authors. Fernández-Luqueño et al. $(2008,2010)$ stated that the SPAD units decreased abrupt and significantly as soon as onset the plant senescence processes. Additionally, Hong et al. (2005) reported that leaves of spinach (Spinacia oleracea L.) treated with $\mathrm{TiO}_{2}$ nanoparticles had higher levels of photosynthesis compared to untreated leaves.

Several studies on the application of nanoparticles in a relatively broad range of species have attempted to understand the effect on plant growth. For instance, Lin and Xing (2007) reported that $\mathrm{ZnO}$ nanoparticles can inhibited seed germination of ryegrass. On the other hand, Stampoulis et al. (2009) did not found a cause-effect on seed germination, root elongation and biomass of zucchini (Cucurbita pepo L.) amended with nanoparticles in hydroponic solutions. In this study root fresh weight, root dry weight, root length, shoot fresh weight, shoot dry weight, shoot length, and SPAD units were not significantly different between nanoparticles treatments, compared to the CONTROL treatment $(\mathrm{P}<0.05)$, i.e., NP did not change significantly some biomass parameters such as root or shoot dry weight. NP did not affect significantly the growing processes, but whether some characteristics related to yield components such as those linked to pods or seeds. It is assumed that in this study the NP-induced toxicity might not affect the plant growth. However, it has to be noted that other modes of actions as photo-induced toxicity and NP-dissolved ion effects might elicit toxicity (FernándezLuqueño et al., 2014).

In this research, we found that at least one concentration of HEMATITE, FERRIHYDRITE or MAGNETITE increased significantly the total $\mathrm{N}$ of roots or shoots, the number of pods, dry weight of pods, the number of seeds, and yield of common bean. Burke et al. (2015) reported that $\mathrm{Fe}_{3} \mathrm{O}_{4}$ nanoparticles can affect the root system as wells as leaf phosphorous content from soybean plants (Glycine max (L.) Merr.), but Quoc et al. (2014) found that iron NP increased up 16\% the yield of soybean in comparison with the control sample. In addition, Martinez-Fernandez et al. (2016) found reduction of the root functionality from sunflower plants (Helianthus annuus L.) by iron oxide nanoparticles. On the other hand, at least one concentration of HEMATITE, FERRIHYDRITE or MAGNETITE decreased significantly the fresh or dry weight of pods. Jeyasubramanian et al. (2016) stated that $\mathrm{Fe}_{2} \mathrm{O}_{3}$ nanoparticles increased the stem and root lengths and biomass production of spinach plant (Spinacia oleracea L.), while the effects were dependent of time and dose.

At least one concentration of ZINC OXIDE or TITANIUM DIOXIDE decreased significantly the number of pods, the fresh weight of pods and the number of seeds. Jacob et al. (2013) found that $\mathrm{TiO}_{2} \mathrm{NP}$ did not affect biomass production in common bean plants grown in nutrient solutions at 0,6 , and $18 \mathrm{mmol} \mathrm{Ti} \mathrm{L}^{-1}$. However, Adhikari et al. (2016) stated that application of nano-zinc oxide particles enhanced the auxin 
indole-3-acetic acid (IAA) production in plant roots of maize (Zea mays L.), soybean (Glycine max L.), pigeon pea (Cajanas cajan L.), and ladies finger (Abelmoschus esculentus L.), which subsequently improved the overall growth. In addition, it has been reported that independent of NP type, a concentration of $250 \mathrm{mg} \mathrm{kg}^{-1}$ of $\mathrm{TiO}_{2}$ and $\mathrm{ZnO}$ NP promoted the highest plant height, root length, and biomass (Raliya et al., 2015). These authors stated that zinc oxide NP had a twin role of being an essential nutrient and a co-factor for nutrient mobilizing enzymes.

It is well known that NP are up taken by the vascular network but the accumulation rate in tissue is different for root and shoot systems from each plant species, while each NP type might have a differential interaction ship with cells as effect of the growing stage, NP size, time exposition, and biotic and abiotic factors. These considerations could be the main reason for the wide variability of results when attempting know the effects of NP on plants. Additionally, it has to be highlighted that some plants NPtreated do not show any observable phenotypic changes in overall growth indicating that environmental NP pollution could be dangerously unnoticed.

\section{Conclusions}

None of the five kinds of NP used in this experiment (magnetite, ferrihydrite, hematite, zinc oxide or titanium dioxide) modified significantly the chlorophyll content of common bean plants as witnessed by the SPAD units' values. However, nanoparticles of magnetite, ferrihydrite, hematite, zinc oxide or titanium dioxide modified significantly at least one plant characteristic or one yield component of common bean, such as SPAD units, root length, root total N, shoot length, shoot total nitrogen, pod number, pod fresh weight, pod dry weight, seed number or yield. The nanoparticles with Fe such as magnetite, ferrihydrite, or hematite were those that increased significantly more crops characteristics such as total $\mathrm{N}$ of roots or shoots, the number of pods, dry weight of pods, the number of seeds, and yield of common bean. These finds are an important factor to take into account with regard to the applicability of NP for long-term use in crops but, the selection of the proper NP at their adequate concentration is important for realizing higher benefits for an agrosustainable target. Additionally, there is the need of generating more data on chronic effects from long terms and concentration exposure of nanoparticles in plants, which is important for a better understanding of the potential hazard or risk of these nanoparticles, while more studies are also necessaries in order to identify the highest potential of NP in the rural sector and in the agro-food industry worldwide.

Acknowledgements. This research was founded by 'Ciencia Básica SEP-CONACyT' projects 151881 and 287225, the Sustainability of Natural Resources and Energy Program (Cinvestav-Saltillo), and Cinvestav Zacatenco. M-P G. received grant-aided support from 'Becas Conacyt'. F-L F, T-T LI, L-V F, and P-G L received grant-aided support from 'Sistema Nacional de Investigadores (SNI)', Mexico.

\section{REFERENCES}

[1] Adhikari, T., Kundu, S., Rao, A. S. (2016): Zinc delivery to plants through seed coating with nano-zinc oxide particles. - Journal of Plant Nutrition 39(1): 139-149.

[2] Anderson, R., Ryser, P. (2015): Early autumn senescence in red maple (Acer rubrum L.) is associated with high leaf anthocyanin content. - Plants 4(3): 505-522. 
[3] Bremner, J. M. (1996): Total Nitrogen. - In: Sparks, D. L. (ed.) Methods of Soil Analysis Chemical Methods, Part 3. Soil Science Society of America Inc., American Society of Agronomy, Madison, WI, USA.

[4] Burke, D. J., Pietrasiak, N., Situ, S. F., Abenojar, E. C., Porche, M., Kraj, P., Lakliang, Y., Samia, A. C. S. (2015): Iron oxide and titanium oxide nanoparticle effect on plant performance and root associated microbes. - International Journal of Molecular Science 16: 23630-23650.

[5] Canas, J. E., Long, M. Q., Nations, S., Vadan, R., Dai, L., Luo, M. X., Ambikapathi, R., Lee, E. H., Olsyk, D. (2008): Effects of functionalized and nonfunctionalized singlewalled carbon nanotubes on root elongation of select crop species. - Environmental Toxicology and Chemistry 27(9): 1922-1931.

[6] Cornelis, G., Hund-Rinke, K., Kuhlbusch, T., Van den Brink, N., Nickel, C. (2014): Fate and bioavailability of engineered nanoparticles in soil: a review. - Critical Reviews in Environmental Science and Technology 44(24): 2720-2764.

[7] Doshi, R., Braida, W., Christodoulatos, C., Wazne, M., O’Connor, G. (2008): Nanoaluminum: transport through sand columns and environmental effects on plants and soil communities. - Environmental Research 106(3): 296-303.

[8] Fernández-Luqueño, F., Dendooven, L., Munive, A., Corlay-Chee, L., SerranoCovarrubias, L. M., Espinosa-Victoria, D. (2008): Micro-morphology of common bean (Phaseolus vulgaris L.) nodules undergoing senescence. - Acta Physiologiae Plantarum 30(4): 545-552.

[9] Fernández-Luqueño, F., Reyes-Varela, V., Martínez-Suárez, C., Salomon-Hernández, G., Yañez-Meneses, J., Ceballos-Ramirez, J. M., Dendooven, L. (2010): Effect of different nitrogen sources on plant characteristics and yield of common bean (Phaseolus vulgaris L.). - Bioresource Technology 101(1): 396-403.

[10] Fernández-Luqueño, F., López-Valdez, F., Valerio-Rodríguez, M. F., Pariona, N., Hernández-López, J. L., García-Ortíz, I., López-Baltazar, J., Vega-Sánchez, M. C., Espinosa-Zapata, R., Acosta-Gallegos, J. A. (2014): Effects of Nanofertilizers on Plant Growth and Development, and Their Interrelationship with the Environment, pp. 211224. - In: López-Valdez, F., Fernández-Luqueño, F. (eds.). Fertilizers: Components, Uses in Agriculture and Environmental Impact. NOVA Science, New York, USA.

[11] Fernández-Luqueño, F., López-Valdez, F., Dendooven, L., Luna-Suarez, S., CeballosRamírez, J. M. (2016): Why wastewater sludge stimulates and accelerates removal of PAHs in polluted soils? - Applied Soil Ecology 101: 1-4.

[12] Gardner, W. H. (1986): Water Content. - In: Klute, A. (ed.) Methods of Soil Analysis. Physical and Mineralogical Methods, Part 1. Soil Science Society of America Inc., American Society of Agronomy, Madison, WI, USA.

[13] Gee, G. W., Bauder, J. W. (1986): Particle Size Analysis. - In: Klute, A. (ed.) Methods of Soil Analysis, Part 1. Physical and Mineralogical Methods. Soil Science Society of America Inc., American Society of Agronomy, Madison, WI, USA.

[14] Gomez, E. J. B., Castaneda, C. L., Shibata, J. K., Gallegos, J. A. A., Colin, S. M., Perez, N. M. (2011): Advances in Mexico on bean breeding for tolerance to high temperature and drought. - Revista Fitotecnia Mexicana 34(4): 247-255.

[15] Hong, F., Zhou, J., Liu, C., Yang, F., Wu, C., Zheng, L. (2005): Effect of nano-TiO ${ }_{2}$ on photochemical reaction of chloroplast of spinach. - Biological Trace Element Research 105: 269-279.

[16] Jacob, D. L., Borchardt, J. D., Navaratnam, L., Otte, M. L., Bezbaruah, A. N. (2013): Uptake and translocation of $\mathrm{Ti}$ from nanoparticles in crops and wetland plants. International Journal of Phytoremediation 15(2): 142-153.

[17] Jeyasubramanian, K, Thoppey, U. U. G., Hikku, G. S., Selvakumar, N., Subramania, A., Krishnamoorthy, K. (2016): Enhancement in growth rate and productivity of spinach grown in hydroponics with iron oxide nanoparticles. - RSC Advances 6(19): 1545115459. 
[18] Keller, A. A., McFerran, S., Lazareva, A., Suh, S. (2013): Global life cycle releases of engineered nanomaterials. - Journal of Nanoparticle Research 15(6), UNSP 1692.

[19] Lépiz, I. R., López. J. J., Sánchez, J. J., Santacruz, R. F., Nuño, R. R., Rodríguez, G. E. (2010): Características morfológicas de formas cultivadas, silvestres e intermedias de frijol común de hábito trepador. - Revista Fitotecnia Mexicana 33(1): 21-28.

[20] Lin, D. H., Xing, B. S. (2007): Phytotoxicity of nanoparticles: inhibition of seed germination and root growth. - Environmental Pollution 150(2): 243-250.

[21] Ma, X. M., Geiser-Lee, J., Deng, Y., Kolmakov, A. (2010): Interactions between engineered nanoparticles (ENPs) and plants: Phytotoxicity, uptake and accumulation. Science of the Total Environment 408(16): 3053-3061.

[22] Markwell, J., Osterman, J. C., Mitchell, J. L. (1995): Calibration of the Minolta SPAD502 leaf chlorophyll meter. - Photosynthesis Research 46: 467-472.

[23] Martinez-Fernandez, D., Barroso, D., Komarek, M. (2016): Root water transport of Helianthus annuus L. under iron oxide nanoparticles exposure. - Environmental Science and Pollution Research 23(2): 1732-1741.

[24] Maurer-Jones, M. A., Gunsolus, I. L., Murphy, C. J., Haynes, C. L. (2013): Toxicity of engineered nanoparticles in the environment. - Analytical Chemistry 85(6): 3036-3049.

[25] Pariona, M. N. (2012): Efecto de nanoparticulas de óxido de hierro en la germinación y crecimiento de tres especies forestales. - M. Sc. Thesis. Universidad de la Sierra Juárez Oaxaca, Mexico.

[26] Quoc, B. N., Trong, H. D., Hoai, C. N., Xuan, T. T., Tuong, V. N., Thuy, D. K., Thi, H. $\mathrm{H}$. (2014): Effects of nanocrystalline powders ( $\mathrm{Fe}, \mathrm{Co}$ and $\mathrm{Cu}$ ) on the germination, growth, crop yield and product quality of soybean (Vietnamese species DT-51). Advances in Natual Sceinces: Nanosciences \& Nanotechnology 5(1): 015016.

[27] Raliya, R., Nair, R., Chavalmane, S., Wang, W. N., Biswas, P. (2015): Mechanistic evaluation of translocation and physiological impact of titanium dioxide and zinc oxide nanoparticles on the tomato (Solanum lycopersicum L.) plant. - Metallomics 7(12): 1584-1594.

[28] Rhoades, J. D., Mantghi, N. A., Shause, P. J., Alves, W. (1989): Estimating soil salinity from saturated soil-paste electrical conductivity. - Soil Science Society of America Journal 53: 428-433.

[29] Rico, C. M., Majumdar, S., Duarte-Gardea, M., Peralta-Videa, J. R., Gardea-Torresdey, J. L. (2011): Interaction of nanoparticles with edible plants and their possible implications in the food chain. - Journal of Agricultural Food and Chemistry 59: 3485-3498.

[30] Ribeiro de Cunha, A., Katz, I., de Pádua Sousa, A., Martinez Uribe, R. A. (2015): Índice SPAD en el crecimiento y desarrollo de plantas de lisianthus en función de diferentes dosis de nitrógeno en ambiente protegido. - Idesia (33)2: 97-195.

[31] Rodrigues, S. M., Trindade, T., Duarte, A. C., Pereira, E., Koopmans, G. F., Römkens, P, F. A. M. (2016): A framework to measure the availability of engineered nanoparticles in soils: Trends in soil tests and analytical tools. - Trends in Analytical Chemistry 75: 129-140.

[32] SAS Institute (1989): Statistic Guide for Personal Computers. Version 6.04. - SAS Institute, Cary, NC.

[33] Stampoulis, D., Sinha, S. K., White, J. C. (2009): Assay-dependent phytotoxicity of nanoparticles to plants. - Environmental Science \& Technology 43(24): 9473-9479.

[34] Thomas, G. W. (1996): Soil pH and Soil Acidity. - In: Sparks, D. L. (ed.) Methods of Soil Analysis: Chemical Methods Part 3. Soil Science Society of America Inc., American Society of Agronomy Inc., Madison, WI, USA. 